\title{
Concise Information for the Frontline Health care workers in the era of COVID-19
}

Pratima Gupta ${ }^{1}$, Aroop Mohanty ${ }^{2}$,Himanshu Narula ${ }^{3}$, Vanya Singh ${ }^{4}$, Deepiyoti Kalita ${ }^{5}$, Saurabh Varshney ${ }^{6}$ Ankita Kabi ${ }^{7}$, Pradeep Aggarwal ${ }^{8}$

${ }^{1}$ Professor, Department of Microbiology, All India Institute of Medical Sciences, Rishikesh, Uttarakhand; ${ }^{2}$ Assistant Professor, Department of Microbiology, All India Institute of Medical Sciences, Rishikesh, Uttarakhand; ${ }^{3}$ Assistant Professor, Department of Microbiology, All India Institute of Medical Sciences, Rishikesh, Uttarakhand; ${ }^{4}$ Senior Resident, Department of Microbiology, All India Institute of Medical Sciences, Rishikesh, Uttarakhand; ${ }^{5}$ Associate Professor, Department of Microbiology, All India Institute of Medical Sciences, Rishikesh, Uttarakhand; ${ }^{6}$ Professor and Head, Department of ENT, All India Institute of Medical Sciences, Rishikesh, Uttarakhand; ${ }^{7}$ Assistant Professor Department of Emergency Medicine, All India Institute of Medical Sciences, Rishikesh, Uttarakhand; ${ }^{8}$ Associate Professor, Department of Community \& Family Medicine, All India Institute of Medical Sciences, Rishikesh, Uttarakhand

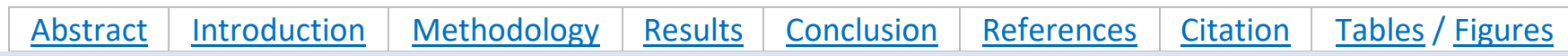

\section{Corresponding Author}

Dr. Aroop Mohanty, Assistant Professor, Department of Microbiology, All India Institute of Medical Sciences, Rishikesh, Uttarakhand

E Mail ID: aroopmohanty7785@yahoo.com

\section{Citation}

Gupta P, Mohanty A, Narula H, Singh V, Kalita D, Varshney S, Kabi A, Aggarwal P. Concise Information for the Frontline Health care workers in the era of COVID-19- A Review. Indian J Comm Health. 2020;32(2-Special Issue):215-224.

Source of Funding: Nil Conflict of Interest: None declared

\section{Article Cycle}

Received: 04/04/2020; Revision: 10/04/2020; Accepted: 15/04/2020; Published: 20/04/2020

This work is licensed under a Creative Commons Attribution 4.0 International License.

\section{Abstract}

Background: COVID-19, a disease caused by SARS-CoV-2 has become a public health emergency of worldwide concern. Originated in Wuhan District of China, it has spread globally at a very rapid rate causing millions of deaths worldwide. Aims and Objectives: To summarize findings from all the current literature available from different databases regarding the epidemiological, clinical characteristics, laboratory diagnosis, treatment, prevention and control of the SARS-CoV-2. This will help out the reader to have a fine gist of all the data available on SARS-CoV-2 in an effective manner. Methods: All the research literature from Jan-March 2020 and available on the following online databases: bio-Rxiv, PubMed, Google Scholar, Embase as well as CNKI and Wang Fang data were included in the review. The keywords used for data search were "coronavirus," "nCoV," "2019-nCoV," and "COVID-19." Conclusion: After undergoing extensive literature search, it can be concluded that it mainly effects elderly male population. Mode of transmission is droplet transmission and human to human transmission is present. The main diagnostic modality remains molecular assays though several rapid testing methods are on the way. Due to lack of specific treatment guidelines, Infection control and supportive treatment remain the mainstay. Plethora of experiments are under trails for development of effective vaccine which can be a ray of hope in future.

\section{Keywords}

Frontline Health Care Workers; COVID-19; Epidemiology Introduction

Coronaviruses are enveloped non-segmented positive sense RNA viruses belonging to the family

Coronaviridae and the order Nidovirales. They are broadly distributed in humans and other mammals.(1) Coronaviruses can cause multiple system infections in various animals but mainly lead 
to respiratory tract infections in humans. $(2,3)$ Although most of the human infections are mild, the epidemics of the other two betacoronaviruses, severe acute respiratory syndrome coronavirus (SARS-CoV) and Middle East respiratory syndrome coronavirus (MERS-CoV) have caused more than 10,000 deaths in the past two decades. Among these two, MERS-CoV showed high mortality rate of $37 \%$ in comparison to $10 \%$ of SARS-CoV. $(4,5)$

On December 31 2019, a series of pneumonia cases of unknown origin were reported in Wuhan, Hubei Province, People's Republic of China (PRC) with clinical features resembling to those of viral pneumonia to WHO.(6) Later on it was found that similar symptoms were seen for the first time in a patient in the same province on December 82019. After deep sequencing analysis from the lower respiratory tract samples, the Chinese Centre for Disease Control and Prevention (CDC) declared on January 7 , that this novel coronavirus pneumonia (NCP) was caused by novel coronavirus (2019-nCoV). Subsequently the WHO on January 27 officially named the novel coronavirus as severe acute respiratory syndrome coronavirus 2 (SARS-CoV-2) and the disease as COVID-19 on 11 February. $(7,8)$ On 13 March 2020, data published by the World Health Organization showed that, since 12 December 2019 when the first case was reported, $17,73,084$ cases have been confirmed to be infected by SARS-CoV-2 and 1,11,652 individuals have died in total.(9) In the meantime, 16,89,487 cases were confirmed and 1,08,301 died in countries outside of China with the maximum deaths in Italy, Spain, France, Iran and USA. India has reported 9152 confirmed cases with 308 deaths till 13th April.

Thus, this has posed a great threat to global public health. Given the rapid spread of the new coronavirus and its impact on global health, the research community has responded with many preliminary research articles about this pandemic. We conducted a review to summarize and critically analyze all published scientific articles regarding coronavirus.

\section{Aims \& Objectives}

To describe the epidemiological, clinical characteristics, laboratory diagnosis, treatment as well as prevention and control of the SARS-CoV-2, so that it can provide meaningful information for future research related to this topic and help readers to have the latest understanding of this new infectious disease.

\section{Material \& Methods}

In this review, all research articles published in the three months from Jan-March 2020 were analyzed and discussed to better understand the epidemiology, clinical features, laboratory diagnosis, treatment, prevention and control of this virus. Four researchers independently searched through the literature, two of them collected all the relevant articles and the rest two reviewed all the selected abstracts. Literature for this review was identified by searching the following online databases: bioRxiv, PubMed, Google scholar, Embase as well as CNKI and WangFang data (the two primary databases for research in China). We searched scientific publications from 1 January to 31st March 2020 using the keywords "coronavirus," "nCoV," "2019nCoV," and "COVID-19." In view of the urgency of the topic and to increase the search sensitivity, a gray literature search was performed using the same keywords on Google Scholar. Furthermore, the WHO database of publications on novel coronavirus was screened for potentially relevant publications.(9) We included all relevant scientific publications written in English or Chinese in this review. In addition, some papers published online by the National Health Commission of the People's Republic of China, Chinese Centre for Disease Prevention and Control were included in the analysis. Non-scientific commentaries, reports and news articles were excluded from this analysis. Based on the main research objectives, articles were classified into one of the following research domains: epidemiology, clinical manifestations, diagnosis, treatment or prevention and control. "Epidemiology" included studies on the epidemic distribution (when, where, who); clinical manifestations and diagnosis included studies on the clinical features (signs and symptoms) and laboratory diagnosis; and prevention control included studies on prevention, control and treatment measures.

EPIDEMIOLOGY: COVID 19 was declared as a public health emergency of International concern on 30th January 2020 by WHO and as a Global Pandemic by WHO on 11th March.(10)

ORIGIN: The cluster of patients with pneumonia of unknown etiology reported from Wuhan City 
towards the end of December 2019 were linked to a local Huanan South China Seafood Market ("wet market").(11)

MODES OF TRANSMISSION: Available evidence indicates that the virus is transmitted directly from person to person when a COVID-19 case coughs or exhales producing droplets that reach the nose, mouth or eyes of another person. Alternatively, as the droplets are too heavy to be airborne, they land on inanimate objects and surfaces, which become a source of infection for others. Transmission through smaller droplet nuclei (airborne transmission) that propagate through air at distances longer than 1 meter is limited to aerosol generating procedures i.e. endotracheal intubation, bronchoscopy, open suctioning, administration of nebulized treatment, manual ventilation before intubation, turning the patient to the prone position, disconnecting the patient from the ventilator, non-invasive positivepressure ventilation, tracheostomy, and cardiopulmonary resuscitation.

SOURCES OF INFECTION: In addition to respiratory droplets researchers have also detected SARS-CoV-2 in stool, gastrointestinal tract, saliva, urine, tears and conjunctival samples. $(12,13)$ It was observed that most of the early cases had some contact history with the original seafood market. $(14,15)$ Gradually over a period of time, a secondary source of infection as human-to-human transmission via close contact was observed.

AGE AND GENDER: Most studies reported involvement of adult patients between 25 and 89 years, majority of them being males. $(16,17)$ There were fewer cases among children and infants.(18) Elderly citizens appear to be the most susceptible group with the median age of death being 75 years and most of them had comorbidities (diabetes, hypertension, heart disease) or history of surgery before admission.(19)

Basic reproductive number (RO)) refers to the average number of new infections generated by an infectious person in a totally naïve population indicating the risk of an infectious agent with respect to epidemic spread. The COVID-19 has been found to have a basic reproductive number (RO) of 3.28 quite similar to that of SARS $(2-5) \cdot(20,21,22)$

This is expected due to the similarities of both pathogen and region of exposure. But despite the intensified public awareness and impressively strong interventional response all over the world, the COVID-19 is already more widespread and is spreading more rampantly than SARS, indicating that it may be more transmissible.

INCUBATION PERIOD: Our current understanding about the incubation period of COVID-19 is limited but most of the studies have estimated the average incubation period to be 5-7 days with a range from 2 to 14 days. $(23,24)$ These estimates of the incubation period of SARS-CoV-2 are also in line with those of other known human coronaviruses, including SARS (mean, 5 days; range, 2 to 14 days) and MERS (mean, 5 to 7 days; range, 2 to 14 days. $(25,26)$

In China, 11,791 cases were confirmed as on 31 January 2020 whereas this number has increased to 83,597 in China as on 13 April 2020. The spread of COVID-19 has been rapid and at present it has spread to almost every country in the world with Italy $(19,901)$ and Spain $(16,972)$ reporting more deaths than China (3,351). Only few countries are spared from this pandemic like Egypt, Angola, Morocco, Mauritius and Uganda. USA at present is the worst affected country and it has left China far behind. It now has the most number of confirmed cases $(5,24,514)$ with a rapid increase in new cases and deaths. On 13 March 2020, a total of 17,73,084 cases have been confirmed of which 1,11,652 individuals have died.(27) In India till date 9152 confirmed cases have been reported out of which 308 individuals have died.

\section{CLINICAL FEATURES:}

Case definitions given by World Health Organization and further adopted by National Communicable Disease Centre, India.(28)

\section{Suspect Case:}

A patient with acute respiratory illness ffever and at least one sign/symptom of respiratory disease (e.g., cough, shortness of breath)\}, AND a history of travel to or residence in a country/area or territory reporting local transmission of COVID-19 disease during the 14 days prior to symptom onset;

OR

A patient/Health care worker with any acute respiratory illness AND having been in contact with a confirmed COVID-19 case in the last 14 days prior to onset of symptoms;

\section{OR}

A patient with severe acute respiratory infection \{fever and at least one sign/symptom of respiratory disease (e.g., cough, shortness breath)\} AND requiring hospitalization AND with no other etiology that fully explains the clinical presentation;

OR 
A case for whom testing for COVID-19 is inconclusive.

\section{Laboratory Confirmed case:}

A person with laboratory confirmation of COVID-19 infection, irrespective of clinical signs and symptoms The most common population effected were adult males in age group of 45-55. Median incubation period from onset of symptoms to admission in hospital was 4-8 days. Clinical symptoms at the onset of illness were similar to other respiratory viruses except gastrointestinal symptoms very rare in SARS-CoV-2 which shows a different tissue tropism of virus as compared to SARS-CoV, MERS-CoV and influenza virus. Most common symptoms of COVID19 patients were fever, cough, myalgia, and shortness of breath. $(7,11,29,30,31)$ Less common symptoms were headache, diarrhea, vomiting, hemoptysis and sputum production. Among elderly population developing disease at least one or more of coexisting illness was present: Chronic pulmonary obstructive disease, diabetes, hypertension or cardiovascular disease. The radiological findings were similar to those of community acquired pneumonia caused by other organisms. Chest CT abnormalities were bilateral involvement of lungs with ground glass opacities and patchy shadowing. $(32,33)$ The most common laboratory findings in patients requiring admission to hospital were lymphopenia and thrombocytopenia. Reduced number of CD4 and CD8 cells and increased cytokines levels were more common in ICU patients than non ICU patients.(34) Other laboratory findings included increased prothrombin time and D-dimer, altered aspartate aminotransferase and alanine aminotransferase, increased creatinine kinase, increased lactate dehydrogenase, abnormal myocardial enzymes.(35) Common complications included ARDS, acute cardiac injury, acute kidney injury and secondary infections leading to septic shock leading to death.

\section{LABORATORY DIAGNOSIS:}

As issued by ICMR the decision of performing laboratory tests for confirmation depends on clinical and epidemiological factors and the following should be suspected and tested for COVID-19.(36)

1. All symptomatic individuals who have undertaken international travel in the last 14 days

2. All symptomatic contacts of laboratory confirmed cases

3. All symptomatic health care workers

4. All patients with Severe Acute Respiratory Illness (fever AND cough and/or shortness of breath)
5. Asymptomatic direct and high-risk contacts of a confirmed case should be tested

once between day 5 and day 14 of coming in his/her contact

In hotspots/cluster (as per Ministry of Health and Family Welfare) and in large migration gatherings/evacuees centers

6. All symptomatic ILI (fever, cough, sore throat, runny nose)

1. Within 7 days of illness - rRT-PCR

2. After 7 days of illness - Antibody test (If negative, confirmed by rRT-PCR)

The above testing strategy may change as per the stage of transmission in community.

The laboratory diagnosis may be done by(37) (Table 1)

Currently, 166 Government Laboratories are approved and supported (provided diagnostic kits or reagents) by ICMR while 70 private laboratories are also approved for testing.

\section{Tests approved by ICMR in India}

US FDA EUA/CE IVD approved kits can be used directly after due approval from DCGI and intimation to ICMR. Following are the non- US FDA EUA/CE IVD validated for use by ICMR(38) (Table 2)

\section{Other Diagnostic Testing:}

In the early stage of the disease, a normal or decreased total white blood cell count and a decreased lymphocyte count can be demonstrated. Lymphopenia appears to be a negative prognostic factor. LFTs elevated more commonly than in typical Community-Acquired Pneumonia cases. Procalcitonin value is usually found to be normal. In critical patients, D-dimer value is increased, persistent lymphopenia and laboratory alterations reflecting multi-organ imbalance (high amylase, coagulation disorders, etc.) are found.

Chest CT may show ground-glass opacities that may evolve into consolidation or ARDS.For the diagnosis of COVID-19, although RT-qPCR is specific, due to false-negative rates leading to misdiagnosis, many clinicians proposed CT scans should be one necessary auxiliary diagnostic method because it is more sensitive.(39)

Combination of pharyngeal RT-PCR and chest CT with higher sensitivity is a reasonable option to screen SARS-CoV-2 infection patients. $(40,41)$

Apart from various serological tests, various POCT tests are under development are Electrical detection of SARS-CoV-2 nucleocapsid protein using nanosensors and aptamer, NGS-based target 
capture for SARS-CoV-2 detection and screening (in development), Indirect immunofluorescence assay for SARS-CoV-2 IgG. (Sensitivity and specificity of this assay have been found to be $100 \%$ therefore may help in follow-up.)

\section{TREATMENT:}

To date, no vaccine or specific antiviral treatment has been confirmed to be effective against COVID19. At present, the treatment of patients with SARSCOV-2 infection is mainly symptomatic and supportive, e.g., oxygenation, ventilation and fluid management.(42) Supplemental oxygen therapy is given to patients with severe respiratory tract infections (SARI) and respiratory distress, hypoxemia, or shock. It is to be initiated at $5 \mathrm{~L} / \mathrm{min}$ and titrated accordingly to reach target $\mathrm{SpO} 2 \geq 90 \%$ in non-pregnant adults and $\mathrm{SpO} 2 \geq 92-95 \%$ in pregnant patients. Children with emergency signs (obstructed or absent breathing, severe respiratory distress, central cyanosis, shock, coma or convulsions) should receive oxygen therapy during resuscitation to target $\mathrm{SpO} 2 \geq 94 \%$; otherwise, the target $\mathrm{SpO} 2$ is $\geq 90 \%$.(43) Appropriate empiric antimicrobials can be administered within one hour of identification of sepsis depending on clinical diagnosis (community-acquired pneumonia, nosocomial pneumonia, or sepsis), local epidemiology and susceptibility data, and treatment guidelines. Empirical therapy includes a neuraminidase inhibitor like oseltamivir for treatment of influenza when there is local transmission or other risk factor / co morbidities including travel history or exposure to animal influenza viruses. Empirical therapy should be deescalated on the basis of microbiology results and clinical judgment.(44)

In accordance with WHO interim guidance, corticosteroids are not recommended as a systemic adjunctive treatment.(45) For patients with progressive deterioration of oxygenation indicators, rapid worsening on imaging and excessive activation of the body's inflammatory response, glucocorticoids can be used for a short period of time ( 3 to 5 days). It is recommended that dose should not exceed the equivalent of methylprednisolone 1$2 \mathrm{mg} / \mathrm{kg} /$ day.

COVID-19 is a mild viral illness in the vast majority of the patients $(80 \%)$ but may cause severe pneumonitis (with subsequent complications) with substantial fatality rates in elderly and individuals with underlying diseases. About $20 \%$ of infected patients need to be admitted, including $5 \%$ who require intensive care. Mortality in admitted patients reached $25 \%$ in the middle of the epidemic. Antiviral therapy should be administered as early as possible after symptom onset for optimal effectiveness particularly in risk groups presenting with mild to moderate disease.(46)

\section{Anti-Viral Drugs:}

Anti-viral drugs used commonly in clinical practice including neuraminidase inhibitors (oseltamivir, paramivir, zanamivir, etc.), ganciclovir, acyclovir and ribavirin are invalid for SARS-CoV-2 and are not recommended.(47) Remdesivir, a nucleotide analogue prodrug has shown broad spectrum antiviral activity against several RNA viruses(Ebola, SARS, MERS).(48) It has been reported to treat the first US case of COVID-19 successfully.(49) Chloroquine, an old anti-malarial has been found to be effective in inhibiting the exacerbation of pneumonia due to its anti-viral and anti-inflammatory properties.(50) Controlled clinical trials have also shown it to be effective in treatment of COVID-19 patients.(50) Protease inhibitors like Lopinavir/Ritonavir( Kaletra) and its combination with interferon- $\beta$ have been successfully used to treat HIV, SARS and MERS-CoV. It significantly decreased the viral loads of a COVID19 patient in Korea.(51) Combination of Chinese and Western medicine also played an important role in treatment of SARS-CoV-2 infection. Lopinavir/ritonavir and Shufeng Jiedu Capsule (SFJDC, a traditional Chinese medicine) led to significant improvement in pneumonia associated symptoms in Shanghai Public Health Clinical Centre, China.(52) Apart from the above other antiviral drugs like Nafamostat, Favipiravir, Ribavirin and Nitazoxamide are under investigation for use.

\section{Convalescent Plasma Therapy:}

Convalescent plasma therapy or SARS-CoV-2-specific hyper immune globulin could be an alternative to drugs and vaccines, and can be used to alleviate the course of disease in severely infected patients. China National Biotec Group Co claimed that 10 seriously ill patients receiving this therapy demonstrated improved oxygenation and reduced inflammation and viral load.(53) Shen et al published a case series of 5 critically ill patients treated with convalescent plasma between day 10 and 22 of admission. The plasma collected from the donors had SARS-CoV-2specific ELISA antibody titer higher than 1:1000 and a neutralizing antibody titer greater than 40 . All 5 patients (age range, 36-65 years; 2 women) were 
receiving mechanical ventilation at the time of treatment and all had received antiviral agents (Kaletra) and methylprednisolone. The clinical conditions of these patients improved, as indicated by body temperature reduction, improved $\mathrm{PAO} 2 / \mathrm{FIO} 2$, and 'chest imaging. Four patients who had been receiving mechanical ventilation and ECMO no longer required respiratory support by 9 days after plasma transfusion.(54)

\section{PREVENTION AND CONTROL:}

To date, there is no effective antiviral treatment or vaccine against this virus. Therefore management of this pandemic totally depends upon the prevention and control of disease transmission. Several public health measures that may prevent or slow down the transmission include: case isolation, identification and follow-up of contacts, environmental disinfection, use of personal protective equipment, precautions for airborne, contact and droplet transmission and ensuring infection control measures. Containment measures, including patient isolation and quarantine, active monitoring of contacts, border controls, and community education and precautions, were performed in Singapore to minimize the disease spread. Due to the successful implementation of such strategy, Singapore has been able to control the COVID-19 outbreak without any major disruption to daily life. This can be used in countries in early stages of the outbreak where it is not possible to mount massive community wide containment efforts.(55)

Infection prevention and control (IPC) measures that may reduce the exposure risk include: use of face masks, covering coughs and sneezes with tissue or flexed elbow, regular hand washing with soap or disinfection with hand rub, social distancing and avoidance of contact with infected people. Hand hygiene and respiratory hygiene with cough etiquette training should be imparted to all health care workers. This will minimize the risk of crossinfection in such high risk areas. According to the WHO guidelines, health care workers involved in aerosol-generating procedures or entering the patient's area have to wear N95 or FFP2 (Filtering face piece).(56,57) This guideline also advices individual without respiratory symptoms to not wear medical masks when in public. Proper use and disposal of masks is essential to avoid any risk of transmission.

Regarding prophylaxis, the National Taskforce for COVID-19 of ICMR recommended the use of
hydoxychloroquine(HCQ) for prophylaxis of SARSCoV-2 infection.(58) Asymptomatic healthcare workers involved in the care of suspected or confirmed cases and asymptomatic household contacts of laboratory confirmed cases are eligible for this prophylaxis.

Studies in Italy have proposed combination therapy of HCQ and Ivermectin for treatment of COVID-19 patients.(59) In a French study, HCQ with azithromycin treatment was significantly associated with significant reduction in viral load and disappearance of COVID-19 patients.(60) The BRACE trial in Australia is a randomized, multi-center clinical trial intended for health care workers to test the use of BCG vaccine against COVID-19. Several other trials for potential vaccine candidates are underway in the US and China and we hope that a vaccine is available soon to curb this pandemic.

\section{Conclusion}

This study shows a complete picture of the current research in response to the outbreak of COVID-19. Initially most of the research papers were based on the epidemiology and causes of SARS-CoV-2 but lately studies focusing on prevention and control measures have begun to increase. Since social media can act as a double-edged sword, it would be pertinent to follow and implement guidelines by CDC, WHO and ICMR. Sharing of evidence based publications information should be widely circulated to aid the frontline physicians who have no time to read individual publications from all over the world.

\section{Authors Contribution}

All authors have contributed equally.

\section{References}

1. Richman DD, Whitley RJ, Hayden FG, eds. Clinical virology 4th edn. Washington: ASM Press, 2016.

2. Yin $Y$, Wunderink RG. MERS, SARS and other coronaviruses as causes of pneumonia. Respirology 2018; 23:130-37.

3. Zaki $A M$, van Boheemen $S$, Besterbroer TM, Osterhaus AD, Fouchier RA. Isolation of a novel coronavirus from a man with pneumonia in Saudi Arabia. N Engl J Med 2012; 367:1814-20.

4. WHO. Summary of probable SARS cases with onset of illness from 1 November 2002 to 31st July 2003. Dec 31, 2003. https://www.who.int/csr/sars/country/table2004_0 4_21/en/ (accessed Mar 29, 2020).

5. WHO. Middle East respiratory syndrome coronavirus (MERS-CoV). 2019. 
http://www.who.int/emrgencies/mers-cov/en/

(accessed Mar 29, 2020).

6. WHO. Novel coronavirus- China. Jan 12, 2020. http://www.who.int/csr/don/12-january-2020novel-coronavirus-china/en/ (accessed Mar 29, 2020).

7. Huang $C$, Wang $Y, \mathrm{Li} X$, Ren $L$, Zhao J, Hu Y, et al. Clinical features of patients infected with 2019 novel coronavirus in Wuhan, China. Lancet (London, England). 2020; 395:497-506.

8. WHO. Rolling updates on Coronavirus disease (COVID 19) updated on 31 March 2020 accessed on 3/04/2020 http: 2www.who.intdiseases. events

9. Organization WH. Coronavirus disease 2019 (COVID19) Situation Report-84.2020.

10. World health Organization website. Rolling updates on Coronavirus disease (COVID 19) updated on 31 March 2020 www.euro.who.international> news

11. World health Organization website. WHO database of publications on coronavirus disease (COVID - 2019). www.who.int/emergencies/diseases/novelcoronavirus-2019/global-research-on-novelcoronavirus-2019-ncov. Accessed March 29,2020.

12. Li Q, Guan X, Wu P, Wang X, Zhou L, Tong Y, et al. Early transmission dynamics in Wuhan, China, of novel coronavirus-infected pneumonia. N Engl J Med. 2020. http://doi.org/10.1056/NEJMoa2001316.

13. Xiao F, Tang M, Zheng X, Li C, He J, Hong Z, et al. Evidence for gastrointestinal infection of SARS-CoV-2. medRxiv.2020:2020.02.17.20023721.

14. Xia J, Tong J, Liu M, Shen Y, Guo D. Evaluation of coronavirus in tears and conjunctival secretions of patients with SARS-CoV-2 infection. Journal of medical virology.2020.

15. Zhou P, Yang XL, Wang XG, Hu B, Zhang W, et al. Discovery of a novel coronavirus associated with the recent pneumonia outbreak in humans and its potential bat origin. bioRxiv. 2020; doi:https://doi.org/10.1101/2020.01.

16. Li T, Wei C, Li W, Hongwei F, Shi J. Beijing Union Medical College Hospital on "pneumonia of novel coronavirus infection" diagnosis and treatment proposal (V2.0) Med J Peking Union Med Coll Hosp 2020.http://kns.cmki.net/kcms/detail/11.5882r.202 00130.1430.002html. Accessed March 302020.

17. Medical expert group of Tongji hospital. Quick guide to the diagnosis and treatment of pneumonia for novel coronavirus infections (third edition). Herald Med

2020.

http://kns.cnki.net/kcms/detila/42.1293.r.20200230

1.1803002 html. Accessed March 292020.

18. Backer JA, Klinkenberg D, Wallinga J. The incubation period of 2019-nCoV infections among travelers from Wuhan. China Euro Surveill.2020;https://doi.org/10.2807/1560-7917. ES.2020.25.5.2000062.
19. Wang $C$, Wang $X$. Prevalence, nosocomial infection and psychological prevention of novel coronavirus infection. Chin General Pract Nurs. 2020; 18:2-3.

20. Wang W, Tang J, Wei F. Updated understanding of the outbreak of 2019 novel coronavirus (2019-nCo V) in Wuhan, China, Journal of medical virology. 2020; 92:441-7.

21. Chen J. Pathogenicity and transmissibility of 2019nCoV-A quick overview and comparison with other emerging viruses. Microbes Infect 2020 Feb 4. pii: S1286-4579(20)30026-5. DOI: 10.1016/j.micinf.2020.01.004. [Epub ahead of print]

22. M. Ceccarelli, M. Berretta, E. Venanzi Rullo, G. Nunnari, B. Cacoparodo. Differences and similarities between Severe Acute Respiratory Syndrome (SARS)Coronavirus (CoV) and SARS-CoV-2. Would a rose by another name smell as sweet? European Review for Medical and Pharmacological Sciences 2020; 24: 2781-2783

23. Ying Liu, Albert A Gayle, Annelies Wilder-Smith, Joacim Rocklöv. The reproductive number of COVID19 is higher compared to SARS coronavirus, Journal of Travel Medicine, Volume 27, Issue 2, March 2020, taaa021, https://doi.org/10.1093/jtm/taaa021

24. Linton NM, Kobayashi $T$, Yang $Y$, et al. Incubation period and other epidemiological characteristics of 2019 novel coronavirus infections with right truncation: a statistical analysis of publicly available case data. J Clin Med. 2020;9. [PMID: 32079150] doi:10.3390/jcm9020538

25. Lauer SA, Grantz KH, Bi Q, et al. The Incubation Period of Coronavirus Disease 2019 (COVID-19) From Publicly Reported Confirmed Cases: Estimation and Application. Ann Intern Med. 2020; [Epub ahead of print 10 March 2020]. doi: https://doi.org/10.7326/M20-0504

26. Varia M, Wilson S, Sarwal S, et al; Hospital Outbreak Investigation Team. Investigation of a nosocomial outbreak of severe acute respiratory syndrome (SARS) in Toronto, Canada. CMAJ. 2003; 169:285-92. [PMID: 12925421]

27. Organization WH. Coronavirus disease 2019 (COVID19) Situation Report-84.2020.

28. W. Guan, Z. Ni, Yu Hu, W. Liang et al. Clinical Characteristics of Coronavirus Disease 2019 in China. N Eng J Med. DOI: 10.1056/NEJMoa2002032

29. Adhikari, S., Meng, S., Wu, Y. et al. Epidemiology, causes, clinical manifestation and diagnosis, prevention and control of coronavirus disease (COVID-19) during the early outbreak period: a scoping review. Infect Dis Poverty 9, 29 (2020). https://doi.org/10.1186/s40249-020-00646-x

30. Chen N, Zhou M, Dong X, Qu J, Gong F, Han Y, et al. Epidemiological and clinical characteristics of 99 cases of 2019 novel coronavirus pneumonia in 
Wuhan, China: a descriptive study. Lancet. 2020; 395:507-13

31. Shi H Han X Jiang N Et al. Radiological findings from 81 patients with COVID-19 pneumonia in Wuhan, China: a descriptive study. Lancet Infect Dis. 2020; (published online Feb 24.) https://doi.org/10.1016/S1473-3099(20)30086-4

32. Chung $M$ Bernheim A Mei $X$ et al. CT imaging features of 2019 novel coronavirus (2019-nCoV). Radiology. 2020; (published online Feb 4. doi: 10.1148/radiol.2020200230

33. Ng M Lee E Yang J Et al. Imaging profile of the COVID19 infection: radiologic findings and literature review. Radiol Cardiothorac Imaging. 2020; 2e200034

34. Bo Diao, Chenhui Wang, Yingjun Tan, Xiewan Chen et.al. Reduction and Functional Exhaustion of T Cells in Patients with Coronavirus Disease 2019 (COVID19). medRxiv 2020.02.18.20024364; doi: https://doi.org/10.1101/2020.02.18.20024364

35. Chaolin Huang, Yeming Wang, Xingwang Li, Lili Ren et al. Clinical features of patients infected with 2019 novel coronavirus in Wuhan, China. Lancet. 2020; 395:497-506.

36. Strategy for COVID19 testing in India (Version 4, dated 09/04/2020) https://icmr.nic.in/sites/default/files/upload_docum ents/Strategey_for_COVID19_Test_v4_09042020.pd $f$

37. https://www.fda.gov/medical-devices/emergencysituations-medical-devices/emergency-useauthorizations\#covid19ivd

38. https://icmr.nic.in/sites/default/files/upload_docum ents/Antibody_based_tests_02042020.pdf

39. Ai T, Yang Z, Hou H, Zhan C, Chen C, Lv W, Tao Q, Sun $\mathrm{Z}$, Xia L. Correlation of chest CT and RT-PCR testing in coronavirus disease 2019 (COVID-19) in China: a report of 1014 cases. Radiology. 2020 Feb 26:200642.

40. Li Y, Xia L. Coronavirus Disease 2019 (COVID-19): Role of chest CT in diagnosis and management. American Journal of Roentgenology. 2020 Feb 21:1-7.

41. Xie X, Zhong Z, Zhao W, Zheng C, Wang F, Liu J. Chest CT for typical 2019-nCoV pneumonia: relationship to negative RT-PCR testing. Radiology. 2020 Feb 12:200343.

42. Huang $C$, Wang $Y$, Li $X$, Ren $L$, Xhao Jianping, $Y$, et al. Clinical features of patients infected with 2019 novel coronavirus in Wuhan, China. Lancet. 2020; 395:497506. https://doi.orh/10.1016/50140-6376(20)301835.

43. Government of India Ministry of Health \& Family Welfare Directorate General of Health Services (EMR Division) Revised Guidelines on Clinical Management $\begin{array}{lll}\text { of COVID } & - & 19\end{array}$ https://www.mohfw.gov.in/pdf/RevisedNationalClini calManagementGuidelineforCOVID1931032020.pdf
44. https://www.who.int/publications-detail/clinicalmanagement-of-severe-acute-respiratory-infectionwhen-novel-coronavirus-(ncov)-infection-issuspected.

45. Organization WH. Clinical management of severe acute respiratory infection (SARI) when COVID- 19 disease is suspected: interim guidance, 13 March 2020. Published Online First: 2020.https://apps.who.int/iris/handle/10665/33144 6 (accessed 16 Mar2020)

46. Interim clinical guidance for adults with suspected or confirmed covid-19 in Belgium 31 march 2020; version 6

47. Li H, Wang YM, Xu JY, Cao B. Potential antiviral therapeutics for 2019 Novel Coronavirus. 2020 Feb 5; 43(0): E002. doi: 10.3760/cma.j.issn.10010939.2020.0002.

48. Tchesnokov EP, Feng JY, Porter DP, Gotte $M$. Mechanism of inhibition of ebola virus rnadependent rna polymerase by remdesivir. Viruses. 2019; 11(4): E326. doi: 10.3390/v11040326.

49. Holshue Michelle L., DeBolt Chas, Lindquist Scott, Lofy Kathy H., Wiesman John, Bruce Hollianne, Spitters Christopher, Ericson Keith, Wilkerson Sara, Tural Ahmet, Diaz George, Cohn Amanda, Fox LeAnne, Patel Anita, Gerber Susan I., Kim Lindsay, Tong Suxiang, Lu Xiaoyan, Lindstrom Steve, Pallansch Mark A., Weldon William C., Biggs Holly M., Uyeki Timothy M., Pillai Satish K. First Case of 2019 Novel Coronavirus in the United States. New England Journal of Medicine. 2020; 382(10):929-936. doi: 10.1056/NEJMoa2001191.

50. Gao J, Tian Z, Yang X. Breakthrough: Chloroquine phosphate has shown apparent efficacy in treatment of COVID-19 associated pneumonia in clinical studies. Biosci Trends. 2020; Available from: http://www.ncbi.nlm.nih.gov/pubmed/32074550.

51. Lim J, Jeon S, Shin HY, Kim MJ, Seong YM, Lee WJ, et al. Case of the index patient who caused tertiary transmission of COVID-19 infection in Korea: the application of lopinavir/ritonavir for the treatment of COVID-19 infected pneumonia monitored by quantitative RT-PCR. J Korean Med Sci. 2020; 35(6): e79. doi: 10.3346/jkms.2020.35. e79.

52. Wang Z, Chen X, Lu Y, Chen F, Zhang W. Clinical characteristics and therapeutic procedure for four cases with 2019 novel coronavirus pneumonia receiving combined Chinese and Western medicine treatment. Biosci 2020. 10.5582/bst.2020.01030

53. China Seeks Plasma From Recovered Patients to Treat Virus I Time. Available from: https://time.com/5784286/covid-19-china-plasmatreatment/. 
54. Shen C, Wang Z, Zhao F, et al. Treatment of 5 Critically III Patients with COVID-19 with Convalescent Plasma. JAMA. Published online March 27, 2020.

55. Vernon J Lee, Calvin J Chiew, Wei Xin Khong, Interrupting transmission of COVID-19: lessons from containment efforts in Singapore, Journal of Travel Medicine, taaa039, https://doi.org/10.1093/jtm/taaa039

56. WHO. Advice on the use of masks in the community, during home care and in health care settings in the context of the novel coronavirus 2019-nCoV outbreak (Interim guidance). 2020. WHO/nCoV/IPC_Masks/2020. Accessed 2 March 2020.

57. Manual on DIY Masks_India_2. Issued by the office of the Principal Scientific advisor to the Government of India. March_30, 2020.
58. ICMR.

https://icmr.nic.in/sites/default/files/upload docum ents/HCQ_Recommendation_22March_final_MM_V 2.pdf

59. Patrì A, Fabbrocini G, Hydroxychloroquine and ivermectin: a synergistic combination for COVID-19 chemoprophylaxis and/or treatment? Journal of the American Academy of Dermatology (2020), doi: https://doi.org/10.1016/j.jaad.2020.04.017.

60. Gautret P, Lagier JC, Parola P, et al. Hydroxychloroquine and azithromycin as a treatment of COVID-19: results of an open-label nonrandomized clinical trial [published online ahead of print, 2020 Mar 20]. Int J Antimicrob Agents. 2020;105949. doi:

\section{Tables}

\section{TABLE 1 LABORATORY DIAGNOSIS}

\begin{tabular}{|c|c|c|c|c|c|}
\hline TYPE OF TESTS & PRINCIPLE & TECHNIQUE & USE & POSITIVE RESULT & Sample \\
\hline $\begin{array}{l}\text { MOLECULAR } \\
\text { TEST }\end{array}$ & $\begin{array}{l}\text { Detects the } \\
\text { presence of viral } \\
\text { genetic material in } \\
\text { a sample }\end{array}$ & $\begin{array}{l}\text { Real time } \\
\text { quantitative } \\
\text { polymerase chain } \\
\text { reaction (RT-qPCR) }\end{array}$ & $\begin{array}{l}\text { Suspected } \\
\text { COVID-19 } \\
\text { patients }\end{array}$ & $\begin{array}{l}\text { Confirms a current } \\
\text { SARS-CoV-2 } \\
\text { infection }\end{array}$ & $\begin{array}{l}\text { BAL, sputum, } \\
\text { nasal swabs, } \\
\text { fibro- } \\
\text { bronchoscope } \\
\text { brush biopsy, } \\
\text { pharyngeal } \\
\text { swabs and } \\
\text { faeces }\end{array}$ \\
\hline $\begin{array}{l}\text { IMMUNO ASSAY } \\
\text { Antibody Based }\end{array}$ & $\begin{array}{l}\text { Detects the } \\
\text { presence of anti- } \\
\text { viral antibodies in } \\
\text { a sample }\end{array}$ & $\begin{array}{ll}\text { Lateral } & \text { flow } \\
\text { immunoassay } & \end{array}$ & $\begin{array}{l}\text { Assessing overall } \\
\text { infection and } \\
\text { immunity rates } \\
\text { in a community }\end{array}$ & $\begin{array}{l}\text { Recent or past } \\
\text { infection, and } \\
\text { could be used to } \\
\text { screen for current } \\
\text { infection }\end{array}$ & \\
\hline Antigen Based & $\begin{array}{l}\text { Detects the } \\
\text { presence of viral } \\
\text { proteins (antigens) } \\
\text { in a sample }\end{array}$ & ELISA & $\begin{array}{l}\text { Suspected/ } \\
\text { Screening }\end{array}$ & $\begin{array}{l}\text { Confirms a current } \\
\text { SARS-CoV-2 } \\
\text { infection or } \\
\text { suggests a } \\
\text { potential infection }\end{array}$ & \\
\hline $\begin{array}{l}\text { POINT OF CARE } \\
\text { TESTS }\end{array}$ & $\begin{array}{l}\text { A rapid, near } \\
\text { patient test for } \\
\text { detection of SARS } \\
\text { CoV-2. } \\
\text { Kits are approved } \\
\text { by FDA for } \\
\text { emergency use } \\
\text { (FDA/EUA). }\end{array}$ & $\begin{array}{l}\text { Cepheid's Gene } \\
\text { Xpert }^{\circledR} \text { Systems } \\
\text { Abbott ID NOW' } \\
\text { COVID-19 test } \\
\text { Chembio Dual Path } \\
\text { Platform COVID-19 }\end{array}$ & $\begin{array}{l}\text { Rapid detection } \\
\text { of SARS- COV-2 } \\
\text { with less than a } \\
\text { minute of hands } \\
\text { on time to } \\
\text { prepare the } \\
\text { sample. } \\
\text { Isothermal } \\
\text { nucleic acid } \\
\text { amplification } \\
\text { technology } \\
\text { Detects } \\
\text { antibodies } \\
\text { against SARS- } \\
\text { CoV-2, only small }\end{array}$ & $\begin{array}{l}\text { Qualitative } \\
\text { detection of SARS- } \\
\text { CoV-2 in } \\
\text { approximately } 45 \\
\text { minutes. } \\
\text { Positive results in } \\
\text { less than five } \\
\text { minutes and } \\
\text { negative results in } \\
13 \text { minutes. } \\
\text { Results within } 15 \\
\text { minutes }\end{array}$ & \\
\hline
\end{tabular}




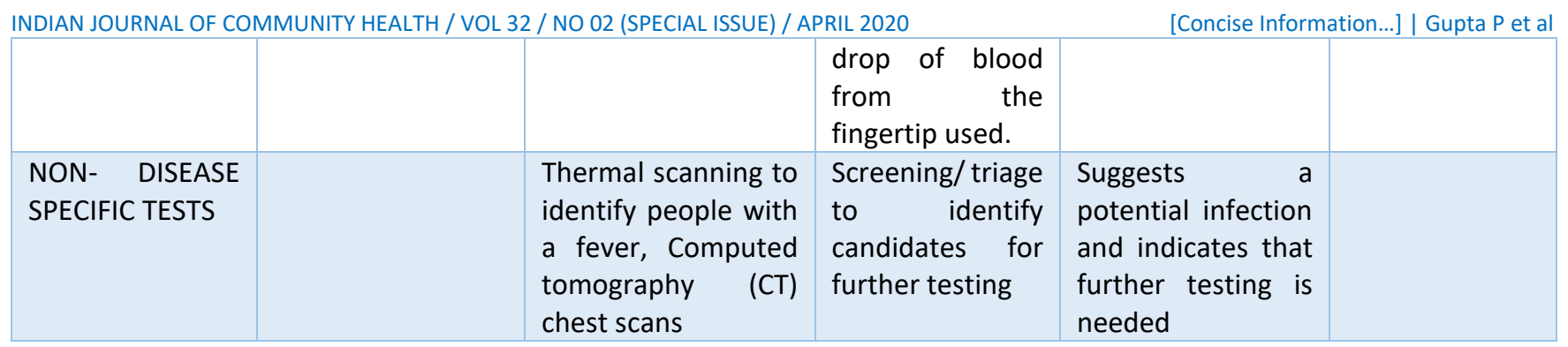

\section{TABLE 2 TESTS APPROVED BY ICMR IN INDIA}

\begin{tabular}{|c|c|c|c|}
\hline \multicolumn{2}{|l|}{ Real-time RT-PCR kits } & \multicolumn{2}{|l|}{ Antibody based rapid tests } \\
\hline Name of company & Name of the Kit & Name of company & Name of the Kit \\
\hline Altona Diagnostics & $\begin{array}{l}\text { RealStar SARS-CoV-2 RT- } \\
\text { PCR kit } 1.0\end{array}$ & $\begin{array}{l}\text { Guangzhou Wondfo Biotech, } \\
\text { Mylan Laboratories Limited (CE- } \\
\text { IVD) }\end{array}$ & $\begin{array}{l}\text { SARS-CoV-2 Antibody test } \\
\text { (Lateral flow method) }\end{array}$ \\
\hline MY LAB & Patho Detect & BioMedomics (CE-IVD) & COVID-19 IgM IgG Rapid Test \\
\hline KILPEST (BLACKBIO) & TRUPCR & $\begin{array}{l}\text { Zhuhai } \\
\text { diagnostics }\end{array}$ & $\begin{array}{lll}\text { COVID-19 } & \text { IgM/IgG } & \text { Antibody } \\
\text { Rapid Test } & & \end{array}$ \\
\hline Seegene & Allplex 2019-nCoV assay & Voxtur Bio Ltd, India & $\begin{array}{l}\text { New Coronavirus (COVID-19) } \\
\text { IgG/IgM Rapid Test }\end{array}$ \\
\hline SD Biosensor & $\begin{array}{l}\text { nCoV Real-Time } \\
\text { Detection kit }\end{array}$ & VANGUARD Diagnostics, India & $\begin{array}{l}\text { COVID-19 IgM/IgG Antibody } \\
\text { Detection card Test }\end{array}$ \\
\hline
\end{tabular}

